\title{
Severe headache following ozone therapy: Pneumocephalus
}

\author{
Ozon tedavisi sonrası şiddetli baş ağrısı: Pnömosefali
}

\author{
Hüseyin TOMAN, ${ }^{1}$ Uğur ÖZDEMIR, ${ }^{2}$ Hasan Ali KiRAZ, ${ }^{1}$ Nurettin LÜLECi ${ }^{3}$
}

\begin{abstract}
Summary
Pneumocephalus is defined as air in the cranial cavity. Pneumocephalus can result from inadvertent dural puncture during lumbar epidural anesthesia or epidural steroid injection. Presently described is case of 41-year-old woman who had undergone lumbar disc hernia operation but due to ongoing complaints, was diagnosed as having failed back surgery syndrome. Percutaneous epidural neuroplasty was performed. In the operating room, under sterile conditions and under sedoanalgesia, Racz catheter was inserted in caudal area and guided to epidural area with scope. In accordance with Madrid Declaration, 20 $\mathrm{ug} / \mathrm{mL}$ concentration and $5 \mathrm{~mL}$ volume oxygen-ozone mixture was injected. After waiting 5 minutes, $0.25 \%$ bupivacaine +80 $\mathrm{mg}$ triamcinolone +1500 units hyaluronidase was administered through the catheter. After epidural neuroplasty procedure, when patient was taken to gurney, she complained of severe headache and nausea. Computed tomography scans of head were done immediately, and consistent with pneumocephalus, air was observed in right lateral ventricle frontal horn, interhemispheric fissure, and superior cerebellar cistern. Patient was placed in Trendelenburg position and intravenous fluid was replaced. Analgesics and bed rest were recommended as treatment. Patient was discharged from hospital on the second day. Within a week, headache pain and other complaints had resolved. In this article, the case of a failed back surgery patient who was postoperatively treated with medical ozone and experienced complication of pneumocephalus is discussed in context of literature data.
\end{abstract}

Keywords: Epidural anesthesia; headache; oxygen-ozone therapy; pneumocephalus.

\begin{abstract}
Özet
Pnömosefali kranial kavitede havanın olmasıdır. Pnömosefali epidural anestezi veya epidural steroid enjeksiyonu sırasında yanIışlıkla duranın delinmesi ile meydana gelebilir. Olgumuz 41 yaşında kadın hasta, lomber disk hernisi tanısı ile opere olmuş fakat şikayetleri devam ediyordu başarısız bel cerrahisi sendromu olduğu düşünüldü. Ameliyathanede sedoanaljezi yapılarak steril koşullarda ve skopi altında RACZ kateteri kaudal bölgeden epidural alana yerleştirildi. İlk olarak Madrid deklarasyonu doğrultusunda $20 \mathrm{ug} / \mathrm{ml}$ konsantrasyon ve $5 \mathrm{ml}$ hacimde oksijen-ozon karışımı epidural aralığa verildi. Perkütan epidural nöroplasti için 5 dakika sonra 1500 Ünite hiyalüronidaz, \%0.25 bupivakain $+80 \mathrm{mg}$ triamsinolon kateterden yapıldı. İşlem sonrası hasta sedyeye alınır iken şiddetli baş ağrısı ve mide bulantısı şikayeti oldu. Hemen bilgisayarlı beyin tomografisi çekildi ve pnömosefali ile uyumlu hava, sağ lateral ventrikül frontal boynuzu, interhemisferik fissür ve süperior serebellar sisternada gözlendi. Hasta Trendelenburg pozisyonuna getirildi ve intravenöz sıvı verildi. Tedavi olarak analjezikler verildi ve yatak istirahati tavsiye edildi. Hasta ikinci gününde taburcu edildi. Baş ağrısı ve şikayetleri bir hafta içinde kayboldu. Bu yazıda başarısız bel cerrahisi sonrası, medikal ozon tedavisinin bir komplikasyonu olarak gelişen pnömosefaliyi literatür bilgileri ışığında tartışmaya çalıştık.
\end{abstract}

Anahtar sözcükler: Epidural anestezi; başağrısı; ozon-oksijen teadvisi; pnömosefali.

\section{Introduction}

Pneumocephalus is described as the presence of air within the cranial cavity. Occurrence of this dysfunction suggests an association between the central nervous system and the outer environment that allows air to reach the intracranial region. This air can be identified radiologically. Pneumocephalus may occur due to accidental dural puncture in cases where resistance loss method is used with air, particularly while administering lumbar epidural anaesthesia or epidural steroid injections. ${ }^{[1]}$ Pneumocephalus presents as a severe headache that is similar to a thunderclap. During differential diagnosis, subarachnoid haemorrhage, colloid cyst of the third ventricle,

\footnotetext{
'Department of Anesthesiology and Reanimation, Çanakkale Onsekiz Mart University Faculty of Medicine, Çanakkale, Turkey

${ }^{2}$ Department of Anesthesiology and Reanimation, Şifa University Faculty of Medicine, İzmir, Turkey

${ }^{3}$ Department of Algology, Private Emsey Hospital, İstanbul, Turkey
}

Submitted (Başvuru tarihi) 09.05.2014 Accepted after revision (Düzeltme sonrası kabul tarihi) 21.03.2016 Available online date (Online yayımlanma tarihi) 03.01.2017

Correspondence (IIletişim): Dr. Hüseyin Toman. Çanakkale Onsekiz Mart Üniversitesi Tıp Fakültesi, Anesteziyoloji ve Reanimasyon Anabilim Dalı, 17100 Çanakkale, Turkey.

Phone (Tel): +90 - 286- 2635950 e-mail (e-posta): huseyintoman01@hotmail.com

(C) 2017 Turkish Society of Algology 
acute sinusitis and intracranial hypotension should be considered. In all the situations, an intracranial pathology should be ruled out by performing radiological investigations. ${ }^{[2]}$ Medical ozone treatment is a minimally invasive method for treating lumbar disk hernia (LDH), and for reducing the volume of herniated disk and the pressure on nerve roots. Furthermore, medical ozone treatment of herniated disk exerts analgesic and anti-inflammatory effects. ${ }^{[3]}$

In this paper, we present a case of pneumocephalus in a patient who received medical ozone treatment after failed back surgery and review the related literature.

\section{Case Report}

A 41-year-old female patient with a 5-year history of lower back pain was diagnosed with LDH. She underwent discectomy plus laminectomy 2 years previously and did not experience pain for a while postoperatively. However, the pain recurred recently, and she visited our clinic after experiencing increased pain levels. Her pain extended from the lower back toward the left leg. Physical examination showed limited flexion of the waist range of motion to the front and left side. Motor power in her lower extremities was $5 / 5$ on both the right and left sides, and there were no sensory defects. Right straight leg raise test (SLRT) was (-) while left SLRT was $60^{\circ}(+)$. Lasegue test on the left leg was $(+)$, with a hand/ground distance of $40 \mathrm{~cm}$. Right and left leg deep tendon reflexes were $(++/++)$. Lumbar contrast magnetic resonance imaging showed granulation tissue at L4-L5 after laminectomy that resulted in root compression on the left side. In addition, both the neural foramina were constricted in the inferior region. The patient was suspected as having failed back surgery syndrome (FBSS), which is one of the most common complications associated with LDH operations. A decision was made to perform percutaneous epidural neuroplasty after obtaining consent from the patient. In the operating room, the patient was maintained in the prone position and the injection area was cleaned under sterile conditions. Next, $1 \mathrm{mg}$ midazolam (Dormi-

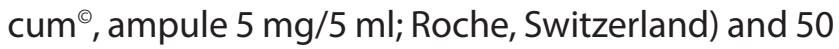
$\mu \mathrm{g}$ fentanyl (Fentanyl-Janssen ${ }^{\odot}$, ampule $500 \mu \mathrm{g} / 10$ $\mathrm{ml}$; Janssen-Cilag, Belgium) were administered for inducing sedoanalgesia, and lidocaine $\mathrm{HCl} 60 \mathrm{mg}$ (Aritmal, ampule 2\%-100 mg/5 ml; Osel Med. Ind, Turkey) was administered subcutaneously for inducing lo- cal anaesthesia. Next, a Racz catheter (Epimed Epidural Needle + Epimed-Radiopaque Epidural Cath), under the guidance of a fluoroscope, was inserted into the epidural space by using the resistance loss method, and the injection site was confirmed using a radiopaque material. In accordance with the Madrid Declaration, $20 \mu \mathrm{g} / \mathrm{ml}$ and $5 \mathrm{ml}$ oxygen-ozone concentration (Hyper-Medozon Comfort; Herrmann Apparatebau $\mathrm{GmbH}$, Kleinwallstadt, Germany) was injected. After $5 \mathrm{~min}, 0.25 \%$ bupivacaine (Marcaine 5\% flacon; Astra Zeneca, Istanbul), 80 mg triamcinolone (Sinakort-A ampule; I.E. Ulagay, Istanbul, Turkey) and $1500 \mathrm{U}$ hyaluronidase (Hyalase ampule; Pharma Dessau GmbH, Dessau, Germany) were administered through the catheter for performing epidural neuroplasty. After the procedure, the patient developed a severe headache and nausea while being transferred to a stretcher. Her arterial pressure was 165$90 \mathrm{mmHg}$, heart rate was $95 / \mathrm{min}$, respiratory count was $16 /$ min and $\mathrm{SpO}_{2}$ was 99 . Physical examination showed bilateral isochoric pupils (diplopy and pupillary dilation), light reflex of $+/+$ and no difference in strength or feeling in the 4 extremities compared with that before the procedure. A computed tomography (CT) scan of the patient's head, which was performed immediately, showed air in the left lateral ventricle frontal horn (Fig. 1). In addition, the head CT scan showed a large collection of air in the interhemispheric fissure and superior cerebellar cistern (Fig. 2) because of which the patient was diagnosed as having pneumocephalus. The patient was placed in the Trendelenburg position, and intravenous fluid replacement was initiated. For the treatment, analgesia and bed rest were recommended. The patient was discharged on day 2 after this procedure when her symptoms decreased and no pneumocephalus was observed on the head CT scan. At follow-up on day 7 , the patient's complaints were completely resolved.

\section{Discussion}

We experienced the case of a patient with rapidly evolving severe headache after percutaneous epidural neuroplasty combined with ozone treatment for FBSS. Clinical investigation of the patient indicated pneumocephalus.

Recently, the interest in minimally invasive procedures, particularly percutaneous techniques, has 


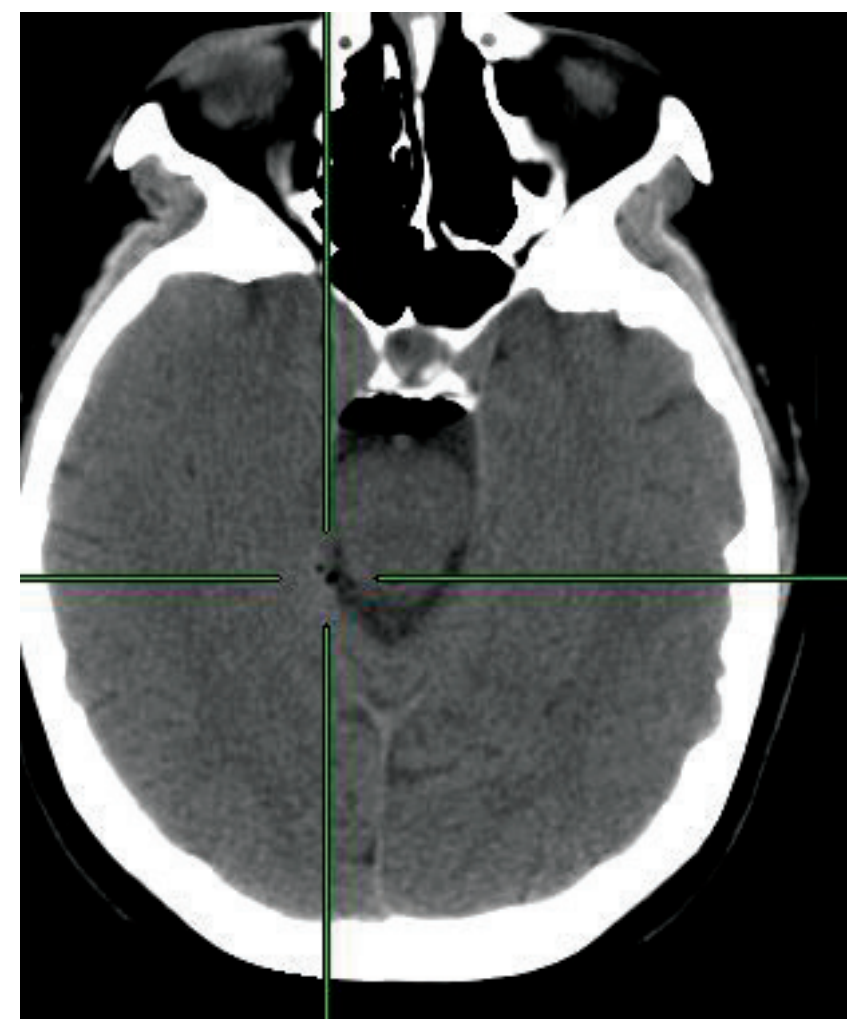

Figure 1. Cranial CT image taken 1 hour after the procedure shows hypodense area compliant with air in the left lateral ventricle anterior horn.

been increasing. Percutaneous interventions are associated with a lower risk of complications and shorter hospital stay than surgical procedures and therefore are being more frequently selected by patients. Ozone treatment is an alternative or supplemental treatment to pharmacological agents and rehabilitation methods for back pain. Ozone $\left(\mathrm{O}_{3}\right)$ is a neutral allotropic form of oxygen, with a molecular weight of 48 $\mathrm{kDa} .{ }^{[4]}$ Ozone treatment is a minimally invasive method that is currently being used frequently. ${ }^{[4]}$ Medical ozone treatment reduces the volume of the herniated disk in intradiscal applications and compression on nerve roots. Furthermore, anti-inflammatory and analgesic properties of ozone reduce pain. ${ }^{[5,6]}$

Studies have indicated that patients with FBSS who are administered ozone treatment show significant reduction in Oswestry disability index; visual analogue scale and analgesic, opioid and adjuvant medication usage accompanied with positive results for modified MacNab criteria. ${ }^{[7-10]}$

Magalhaes et al., ${ }^{[7]}$ successful treated patients with FBSS by using epidural ozone treatment; moreover, these patients did not experience any complica-

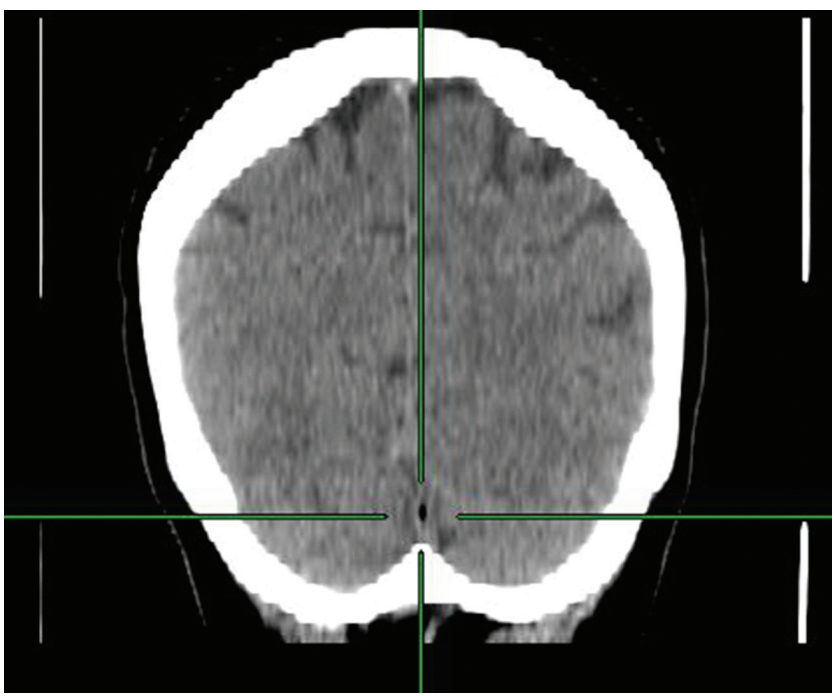

Figure 2. Cranial CT image taken 1 hour after the procedure shows hypodense area compliant with air in the interhemispheric fissure and superior cerebellar cisterna.

tions after the treatment. Magalhaes et al., ${ }^{[7]}$ used a fibre-optic microendoscope in the caudal region to observe the epidural space while inserting the catheter and administered a higher volume of ozone. In our procedure, we entered the caudal region under the guidance of a fluoroscope and performed percutaneous epidural neuroplasty. In addition, we confirmed the location of the epidural space by using a radiopaque material that was administered through the catheter, which was forward into the region.

Alexandre et al., ${ }^{[8]}$ administered ozone treatment to 1027 patients with FBSS. Except 2 patients with discitis, none of the patients experienced any complications. Muto et al. ${ }^{[9]}$ administered ozone treatment to 200 patients with FBSS and reported no neurological and infectious complications in early or late periods.

A meta-analysis of studies on ozone treatment indicated that this treatment is mainly used for patients with herniated disks and has a success rate of $75 \%-$ $80 \%$ in this patient group. Ozone treatment after failed back surgery has a success rate of $40 \%-70 \%$ in patients with problems such as channel stenosis and facet arthrosis. ${ }^{[1]}$ Our patient had severe lower back and leg pain due to a failed back surgery. Various rarely observed complications such as vitreoretinal haemorrhage, paraesthesia associated with spinal nerve damage, vertebrobasilar stroke and pneumocephalus, which has been reported in only 2 known cases, are associated with ozone treatment. ${ }^{[10]}$ 
Chalaupka et al. ${ }^{[11]}$ reported the only 2 cases of pneumocephalus associated with ozone treatment. The first case was of a patient with severe and widespread headache on day 1 after ozone treatment while the second case was that of a patient who was admitted to the hospital with headache and neurological symptoms at 8 months after ozone treatment.

Complications associated with epidural injection, such as dural puncture, vascular injection and subarachnoid haemorrhage, may also be observed. These complications present as sudden onset headache, neurological changes, cardiovascular and respiratory system changes and back and lower back pain. ${ }^{[12]}$ In some cases where epidural steroid administration involves the resistance loss method, symptoms of pneumocephalus are observed 20 min later. ${ }^{[2,13]}$ In our case, severe and widespread headache was observed immediately after the ozone treatment. Two mechanisms have been proposed in the development of pneumocephalus. The first mechanism involves the leakage of cerebrospinal fluid while the second mechanism involves intrathecal injection of air. ${ }^{[14]}$ Because severe headache may be associated with pneumocephalus, at least $2 \mathrm{ml}$ air in the subarachnoid area is sufficient. ${ }^{[15]}$ In our case, we used $5 \mathrm{ml}$ ozone. We believe that ozone acted like air and resulted in the sudden onset of severe headache due to pneumocephalus.

Headache due to dural puncture starts $24-48 \mathrm{~h}$ after the injection; in addition, severe pain that changes with position is observed. Patients with pneumocephalus experience headache that is similar to that after a postdural puncture. Head CT scan should be performed for the differential diagnosis of pneumocephalus. In addition to headache, pneumocephalus may cause confusion, lethargy, hemiparesis and hemiplegia. These symptoms decrease within 2 days as air in the cranial cavity is absorbed and, on an average, resolve completely within 1 week. ${ }^{[2,16,17]}$

Air in the epidural space can lead to various complications such as pneumocephalus, compression of the cauda equina and air embolism. ${ }^{[18]}$ In our case, the epidural space was located using the resistance loss method. However, we believe that ozone directed to the subarachnoid space because of accidental dural puncture acted like air and resulted in pneumocephalus.
In conclusion, headache after ozone treatment, which is currently commonly used for treating lower back pain, should not be taken lightly, and differential diagnosis of pneumocephalus should be considered.

\section{Conflict-of-interest issues regarding the author- ship or article: None declared.}

\section{Peer-rewiew: Externally peer-reviewed.}

\section{References}

1. Kozikowski GP, Cohen SP. Lumbar puncture associated with pneumocephalus: report of a case. Anesth Analg 2004;98(2):524-6.

2. Guarino $A H$, Wright NM. Pneumocephalus after a lumbar epidural steroid injection. Pain Physician 2005;8(2):239,41.

3. Gautam S, Rastogi V, Jain A, Singh AP. Comparative evaluation of oxygen-ozone therapy and combined use of oxygen-ozone therapy with percutaneous intradiscal radiofrequency thermocoagulation for the treatment of lumbar disc herniation. Pain Pract 2011;11(2):160-6.

4. Andreula CF, Simonetti L, De Santis F, Agati R, Ricci R, Leonardi M. et al. AJNR Am J Neuroradiol 2003;24(5):996-1000.

5. Iliakis E, Valadakis V, Vynios DH, Tisiganos CP, Agapitos E. Rationalization of the activity of medical ozone on intervertebral disc: a histological and biochemical study. Riv Neuroradiol 2001;14:23-30.

6. Bocci V, Luzzi E, Corradeschi F, Paulesu L, Di Stefano A. Studies on the biological effects of ozone: 3 . An attempt to define conditions for optimal induction of cytokines. Lymphokine Cytokine Res 1993;12(2):121-6.

7. Magalhães FN, Soares SC, Torres JM, Ungaretti A, Cacciacarro MF, Teixeira MJ, et al. Effects of ozone applied by spinal endoscopy in patients with chronic pain related to failed back surgery syndrome: a pilot study. Neuropsychiatr Dis Treat 2013;9:1759-66.

8. Alexandre A, Corò L, Paradiso R, Dall'aglio R, Alexandre AM, Fraschini F, Spaggiari PG. Treatment of symptomatic lumbar spinal degenerative pathologies by means of combined conservative biochemical treatments. Acta Neurochir Suppl 2011;108:127-35.

9. Muto M, Ambrosanio G, Guarnieri G, Capobianco E, Piccolo $G$, Annunziata $G$, et al. Low back pain and sciatica: treatment with intradiscal-intraforaminal O(2)-O (3) injection. Our experience. Radiol Med 2008;113(5):695-706.

10. Magalhaes FN, Dotta L, Sasse A, Teixera MJ, Fonoff ET. Ozone therapy as a treatment for low back pain secondary to herniated disc: a systematic review and metaanalysis of randomized controlled trials. Pain Physician 2012;15(2):115-29.

11. Devetag Chalaupka F, Caneve G, Mauri M, Zaiotti G. Thunderclap headache caused by minimally invasive medical procedures: description of 2 cases. Headache 2007;47(2):293-5. 
12. Vasdev GM, Chantigian RC. Pneumocephalus following the treatment of a postdural puncture headache with an epidural saline infusion. J Clin Anesth 1994;6(6):508-11.

13. Abram SF, Cherwenka RW. Transient headache immediately following epidural steroid injection. Anesthesiology 1979;50(5):461-2.

14. Aida S, Taga K, Yamakura T, Endoh H, Shimoji K. Headache after attempted epidural block: the role of intrathecal air. Anesthesiology 1998;88(1):76-81.

15. Nolan RB, Masneri DA, Pesce D. Pneumocephalus after epi- dural injections. Emerg Med J 2008;25(7):416.

16. Katz Y, Markovits R, Rosenberg B. Pneumoencephalos after inadvertent intrathecal air injection during epidural block. Anesthesiology 1990;73(6):1277-9.

17. Katz JA, Lukin R, Bridenbaugh PO, Gunzenhauser L. Subdural intracranial air: an unusual cause of headache after epidural steroid injection. Anesthesiology 1991;74:615-7.

18. Ash KM, Cannon JE, Biehl DR. Pneumocephalus following attempted epidural anaesthesia. Can J Anaesth 1991;38(6):772-4. 